(C) В.В. Сацюк, к.т.н., С.А. Красовський, В.В. Федорук Луцький національний технічний університет

\title{
ДОСЛІДЖЕННЯ ПРОЦЕСУ ПРИГОТУВАННЯ СУШИЛЬНОГО АГЕНТУ У СОНЯЧНОМУ ТЕПЛОВОМУ КОЛЕКТОРI
}

У статті описано конструкиію сонячного теплового колектору. Наведено результати дослідження впливу геометричних $i$ технологічних параметрів колектору та температури зовнішнього середовища на температуру приготованого сушильного агенту.

СУШИЛЬНИЙ АГЕНТ, КОЛЕКТОР, ТЕМПЕРАТУРА, ШВИДКІСТЬ, ВИТРАТА, ЧАС, РІВНЯННЯ РЕГРЕСІї

Постановка проблеми. Зниження відносної вологості насіння після збирання більшості сільськогосподарських культур необхідне для тривалого зберігання. Під під час сушіння важливо 
забезпечити мінімальну тривалість дії на насіння, дотримуючись температурного режиму, не перевищуючого норму.

Постійний ріст вартості енергоносіїв посилює пошуки альтернативних, відновних джерел енергії. дослідження доводять, що тиждень на земну поверхню поступає така кількість сонячної енергії, яка перевершує кількість енергії від світових запасів усіх видів палива [1]. Сонячна постійна на екваторі складає 1024 Вт. Перевага сонячної енергетики - невичерпність джерела енергії та загальнодоступність. Тому сьогодні розробка сонячних теплових колекторів та сонячних сушарок $€$ актуальним завданням.

Аналіз останніх досліджень і публікацій. Відомі дослідження процесу використання сонячної енергії [2, 3]. Дані дослідження грунтувались на розробці сушарок, у яких сушіння відбувалось прямим сонячним промінням, без використання сонячних теплових колекторів. Використання сонячних теплових колекторів для підготовки сушильного агенту дозволить використовувати відновлюване джерело енергії у традиційних сушарках.

Мета дослідження. Розробити конструкцію сонячного теплового колектору та провести лабораторно-виробничі його випробування 3 метою встановлення впливу факторів на температуру приготованого сушильного агенту.

Результати дослідження. Для дослідження процесу сушіння насіння сільськогосподарських матеріалів розроблена лабораторна установка (рисунок 1). Установка складається з сушильної камери, гнучкого з'єднання, сонячного теплового колектору, регулюючої засувки, розташованій на колекторі і вентиляторі .

Установка працює таким чином: атмосферне повітря засмоктується вентилятором в колектор, під дією сонячних променів нагрівається в ньому і гнучким з'єднанням подається до сушильної камери . В сушильній камері встановлюються в певній послідовності пронумеровані касети 3 шаром матеріалу певної товщини, початкової вологості і маси. Касета являє собою ємкість циліндричної форми 3 решітчастим дном, крізь яке проходить повітря, але не просипається матеріал. Касети встановлюються одна над одною. Послідовно, через всі касети, проходить сушильний агент, знижуючи вологість матеріалу в кожній касеті. 


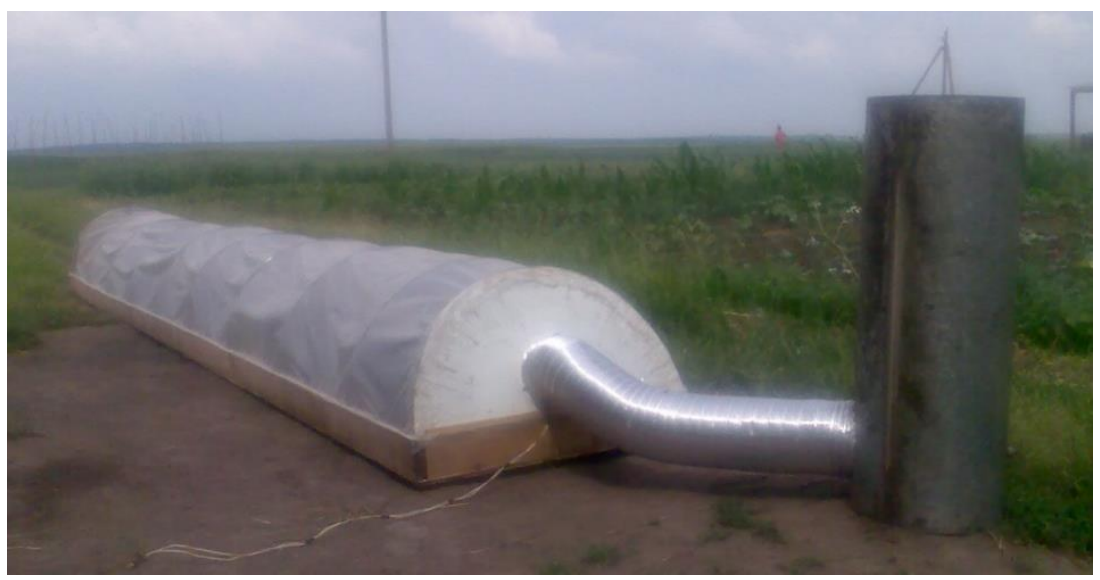

Рис. 1 - Загальний вигляд лабораторної установки сушарки із сонячним тепловим колектором

Для дослідження процесу приготування сушильного агенту використовували лабораторну установку сонячного теплового колектору (рисунок 2). Лабораторна установка складається 3 наступних елементів: дерев'яного каркасу, теплоізоляції, світло відбивного покриття, поглинаючого тіла, у вигляді металевої стружки, металевої сітки, що притискає стружку до дна колектору та світлопрозорого покриття зверху колектора. Теплова ізоляція( може бути пінопласт, мінвата, скловата, товщиною $50-100$ мм) вкладається в нижній частині корпусу, а зверху покривається світло відбивним покриттям для зменшення теплових втрат. 


\section{Сільськогосподарські машини. Випуск 43}
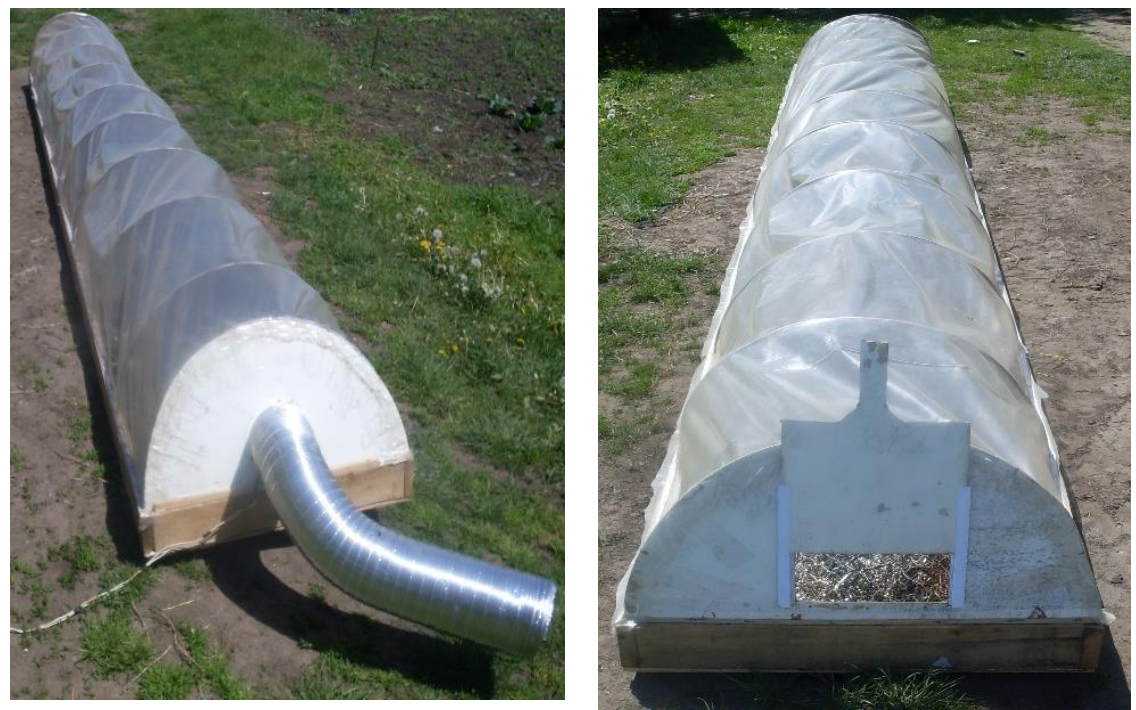

Рис. 2 - Лабораторна установка сонячного теплового колектору

Для дослідження процесу приготування сушильного агенту у сонячному тепловому колекторі, застосовували математичний метод планування експерименту із використанням симетричного не композиційного плану реалізації експерименту Бокса-Бенкіна другого порядку [4]. Метою експерименту було визначення температури приготованого сушильного агенту при варіюванні таких факторів як температура навколишнього середовища, робоча площа колектору та витрата повітря сонячного колектору. Для отримання математичної моделі процесу нагріву сушильного агенту, шляхом пропуску повітря через сонячний колектор було проведено трьох факторний експеримент.

Обробка даних результатів три факторного експерименту згідно з три рівневим планом другого порядку на ЕОМ (за допомогою розробленої у середовищі програми Mathcad 14 ), дозволила отримати рівняння регресії, функцією відгуку якого $\epsilon$ температура сушильного агенту:

$$
\begin{gathered}
\mathrm{Y}=42.556+7.646 \cdot \mathrm{x}_{1}-2,958 \cdot \mathrm{x}_{2}+6.771 \cdot \mathrm{x}_{3}-0.542 \cdot \mathrm{x}_{1} \cdot \mathrm{x}_{2}+ \\
+0.181 \cdot \mathrm{x}_{1}^{2}+0.472 \cdot \mathrm{x}_{2}^{2}-0.319 \cdot \mathrm{x}_{3}^{2}
\end{gathered}
$$

де $\mathrm{x}_{1}$ - кодоване значення вхідної температури повітря;

$\mathrm{x}_{2}$ - кодоване значення витрати сушильного агенту;

$\mathrm{x}_{3}$ - кодоване значення робочої площі колектору; 
Перевірку адекватності отриманого рівняння регресії (1) проводили за допомогою критерію Фішера $\mathrm{F}_{\phi}$, а оцінка значущості коефіцієнтів регресії проводилась за допомогою критерію Стьюдента.

Підставивши фактори у рівняння (1) отримали рівняння регресії у натуральному вигляді:

$$
\begin{aligned}
\mathrm{y}(\mathrm{S}, \mathrm{Q}, \mathrm{T})= & 73.75 \cdot \mathrm{Q}^{2}-11.29 \cdot \mathrm{Q} \cdot \mathrm{T}-105.24 \cdot \mathrm{Q}+0.48 \cdot \mathrm{S}^{2}-, \\
& -0.45 \cdot \mathrm{S}+0.005 \cdot \mathrm{T}^{2}+1.53 \cdot \mathrm{T}+13.49
\end{aligned}
$$

де $\mathrm{T}$ - значення вхідної температури повітря, ${ }^{0} \mathrm{C}$;

$\mathrm{Q}-$-значення витрати сушильного агенту $\mathrm{m}^{3} / \mathrm{c}$;

$\mathrm{S}$ - значення робочої площі колектору, $\mathrm{m}^{2}$.

За отриманим рівнянням регресії (2), були побудовані поверхні відгуку (рисунок 3) та їх двомірні січення для відслідковування динаміки зміни температури сушильного агенту на виході із теплового сонячного колектору.

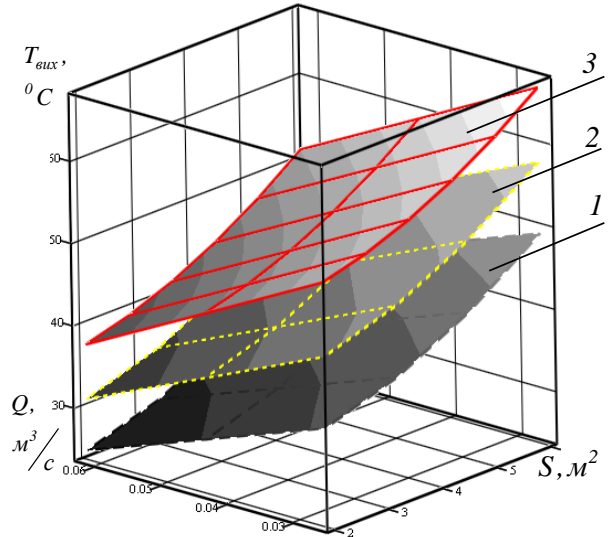

a)

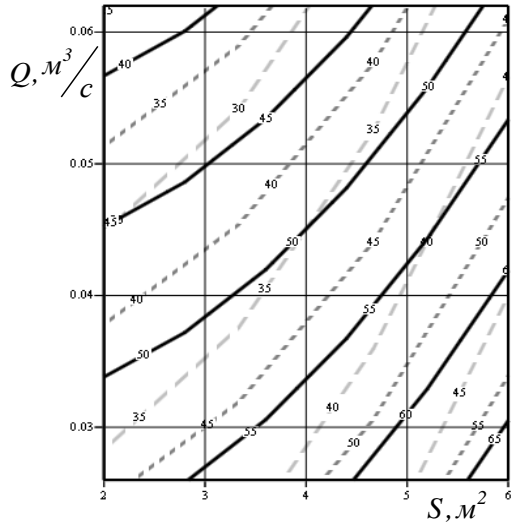

б)

Рис. 3 - Залежність зміни температури сушильного агенту при зміні таких факторів як робоча площа колектору $\mathrm{S}$, та витрата сушильного агенту $Q$ при вхідній температури повітря $T$ :

$$
\text { 1- } \mathrm{T}=18{ }^{0} \mathrm{C} ; 2-\mathrm{T}=24{ }^{0} \mathrm{C}, 3-\mathrm{T}=30^{\circ} \mathrm{C}
$$

Висновки. Аналізуючи отримані поверхні відгуку, можна зробити висновок, що на зміну температури сушильного агенту впливають усі досліджувані фактори. Температура приготованого сушильного агенту зростає із збільшенням вхідної температури повітря та площі теплового колектору. Збільшення витрати 
колектору супроводжується зниженням температури сушильного агенту. Найвища температура сушильного агенту спостерігається при робочій площі колектору $\mathrm{S}=6 \mathrm{M}^{2}$ а витраті $\mathrm{Q}=0,03 \mathrm{M}^{3} / \mathrm{c}$.

\section{Література}

1. Сонце - як джерело енергії - Режим доступу: https://alternative-energy.com.ua.

2. Тюрин Г. Я., Набиханов Б. М., Абидов Т. З. Гелиоустановка для сушки фруктов // Механизация и електрификация сельського хозяйства. - 1989. - №5. - с.37.

3. Умаров Г. Я., Тюрин Г. Я., Набиханов Б. М., Абидов Т. 3. Солничная фруктосушилка с автоматической системой управления// Техника в сельском хозяйстве. - 1988. - №1. - с. 9-10.

4. Новик Ф.С., Арсов Я.Б. Оптимизация процессов технологи металлов методами планирования экпериментов. - М.: Машиностроение, София: Техника, 1980. - 304. 